\title{
THE QUEST FOR HAPPINESS IN WOLE SOYINKA'S THE TRIALS OF BROTHER JERO
}

\author{
Christine Osae \\ Adventist University of Central Africa \\ E-mail: christine.osae@yahoo.com
}

APA Citation: Oase, C. (2016). The quest for happiness in Wole Soyinka's The Trials of Brother Jero. Indonesian EFL Journal, 2(1), 12-22

Received: 14-11-2015

Accepted: 24-12-2015

Published: 01-01-2016

Abstract: In pursuit of happiness, humans have indulged in atrocious acts and lost the moral membrane, perhaps with a conviction that they can find fulfillment. Literature, being a mirror of the society, is the best medium to help in correction of these wrongs. This article is aimed at the analysis of the major fictional characters in Soyinka's The Trials of Brother Jero to reveal their daily struggles in search of happiness. A textual analysis in relation to Aristotle's doctrine of happiness leads to a conclusion that Soyinka has successfully created lifelike characters whose struggles in life are relatable yet unproductive as far as the quest for happiness is concerned.

Keywords: virtue, golden mean, happiness, fulfillment

\section{INTRODUCTION}

Humans are the most endowed of all the creatures, yet with equal measure, the most discontented. Many seek to amass wealth only to become unhappy. Others seek love while some seek honor in futility - it is an endless cycle of unhappiness. A child goes to school, for example, to get knowledge, but he only needs this knowledge to get employed. With employment, he can earn a living-wealth; can it be consequently supposed that he has found happiness? Kenny (2002) argues that "money is only as good as what it can buy. It is how someone spends his money that shows us where he really thinks happiness lies: does he spend it on luxury, for instance, or to gain political power, or give it to those less well off?" (3) Evidently, wealth, honor, pleasure, and love among other things do not guarantee happiness.
A search in the archives of history will reveal that several men of wisdom (Aristotle, Socrates, Plato, and Augustine among others) have taken turns in trying to establish what happiness is or is not and how to be happy but all these attempts have only served to create more confusion. What is shocking though is that despite its nonrepresentational nature, it is a vital end sought after by everyone (Tosin, 2015). As evidenced in Aristotle's (1985) submission, "every craft and every investigation, and likewise every action and decision, seems to aim at some good; hence the good has been well described as that at which everything aims" (Nicomachean Ethics, 1985:1094a1). In this case, Aristotle suggests that this good is the ultimate purpose of human existence. For want of a better name, Aristotle suggests that this great end should be called happiness. 
What is inexplicable however is what people are willing to do to be happy. While some achieve this end virtuously, others will commit the most villainous acts for the same. Often times, people wallow in the miasma of the idiom, the end justifies the means, that it becomes practically impossible for them to realize how wicked their actions are. Literature then becomes our cursor to the right track. It is through textual analysis of literary texts, and an understanding of what characters (though fictional) struggle with, that we can truly understand our own dilemma, and rest assured that we are not alone in this hunt.

The chief claim of this article is that Soyinka's characters, just like other human beings, are vainly in pursuit of happiness and will do anything to attain this elusive end. Using Aristotle's doctrine of happiness the article analyses The Trials of Brother Jero to investigate man's search for happiness and the actions implemented to achieve it.

\section{The Concept of Happiness}

According to Aristotle (1985), happiness is the ultimate end for which there is no other end (Nicomachean Ethics, 1985:1094a1). What this means is that happiness, more than anything else, seems unconditionally complete or self sufficient because we always choose it as an end and not because we want something else after getting it (Nicomachean Ethics, 1985:1097b18). In other words, when one is happy, they will not need anything. The implication here is that only happiness can bring complete fulfillment in life (Bremner, 2011, p. 40). It can therefore be argued that happiness is that which one freely seeks to attain for its own sake.

Today, people seek pleasure, wealth, and a good reputation or honor but these are not ends in themselves.
Aristotle (1985) contends that while each of these has some value, none of them can occupy the place of the chief good for which humanity should aim. Indeed, happiness is the end which meets all these requirements. It is apparent that we desire money, pleasure, and honor only because we believe that these goods will make us happy. This is an indication that all these things are a means to achieving happiness yet happiness is not a means to achieving them.

To bring his point home, Aristotle (1985) explains that man's unique function is to reason. This guarantees that all philosophers are more inclined to be happy as they tend to reason a lot. When we reason out things, we are able to find solutions to our problems hence attain happiness. "We have a rational capacity and the exercising of this capacity is thus the perfecting of our natures as human beings"

(Nicomachean Ethics, 1985:1097b24). For this reason, gratification alone cannot amount to human happiness, for gratification is what animals seek and human beings have higher capacities than animals. Similarly, he argues that instantaneous pleasure that most men seek today is animalistic and does not bring the ultimate happiness; hence, he bewails, "The mass of mankind are evidently quite slavish in their tastes, preferring a life suitable to beasts" (Nicomachean Ethics, 1985:1095b 20).

How then can we be happy? By practicing morality and doing our duties with excellence (Nicomachean Ethics, 1985:1098a13). Simply put, do your jobs diligently and maintain the right moral cord and you will be happy. This introduces a central relationship between moral character and a realization of happiness. He seems to suggest that virtue should ultimately bring fulfillment as opposed to vice, yet in order to achieve virtue we must 
make the right choices which is a tricky undertaking since we are often tempted to choose pleasurable things that may not always be good. Usually, the lesser good promises immediate pleasure and is more tempting, while the greater good is painful and requires some sort of sacrifice (http://www.pursuit-ofhappiness.org/history-ofhappiness/aristotle).

On the relationship between happiness and virtue, Aristotle (1985) says, "happiness is an activity of the soul expressing complete virtue" (Nicomachean Ethics, 1985:1102a513). This, he says can be, "virtue of thought [e.g., wisdom, comprehension, intelligence] or virtue of character [e.g., generosity, temperance, courage, justice] (Nicomachean Ethics, 1985:1103a14).

Furthermore, Aristotle (1985) argues that to be truly virtuous, one must attain the golden mean. This is the mark between excess and deficiency in our actions. As observed in the article Golden Mean, "Today's modern man usually succumbs in the extreme of excess, which can be seen in the uncontrollable accumulation of material wealth, food, alcohol, drugs, but he can descend into deficiency as well. For this reason, Aristotle recommends courage, temperance, liberality, magnificence, proper pride, good temper, modesty, and friendliness as marks of virtue.

In the rule of the golden mean, Aristotle argues that there are three divisions to every behavior- the two extremes and the temperate. "For instance, a person who flees from every danger is cowardly; the one who does not flee from anything is rash. What is courageous, then, falls somewhere between these extremes; courage is "preserved by the observance of the mean" (Nicomachean Ethics, 1985:1104a26). This implies that if one finds a moderate position between those two extremes, they will be acting morally.

Going by Aristotle's designation of happiness, it is futile to pursue it. How many can declare they have lived a truly happy life? How many in the contemporary society can say they have found happiness? Today, a cyber thief will hack someone's personal details, for example, to impersonate him, but he is impersonating him so he can withdraw the victim's savings and use the credit cards. With this money, he can leave a pleasurable life; can it be consequently supposed that he has found happiness? Is pleasure therefore the good Aristotle is talking about? Kenny (2002) argues that "money is only as good as what it can buy. It is how someone spends his money that shows us where he really thinks happiness lies: does he spend it on luxury, for instance, or does he use it to gain political power, or give it to those less well off?" Aristotle (1985) says wealth is merely a useful choice to help us meet another end but is not an end in itself (Nicomachean Ethics, 1985:1096a 6-8). This other end is happiness. Man's life is characterized by this overwhelming need to be happy. In conclusion, Aristotle (1985) makes the following claims as to what happiness is:
Happiness is the ultimate end and purpose of human existence; Happiness is not pleasure, nor is it virtue. It is the exercise of virtue; happiness cannot be achieved until the end of one's life. Hence it is a goal and not a temporary state; happiness is the perfection of human nature. Since man is a rational animal, human happiness depends on the exercise of his reason; happiness depends on acquiring a moral character, where one displays the virtues of courage, generosity, justice, friendship, and citizenship in one's life. These 


\author{
virtues involve striking a balance or \\ "mean" between an excess and a \\ deficiency; happiness requires \\ intellectual contemplation, for this is the \\ ultimate realization of our rational \\ capacities (http://www.pursuit-of- \\ happiness.org/history-of- \\ happiness/aristotle).
}

Simply put, humans passionately chase after happiness utterly ignorant that their own vices are an impediment. Happiness cannot be achieved if one is not virtuous yet virtue is only practiced through right choices.

\section{Plot Synopsis of the Trial of Brother Jero}

According to Mireku (2013), Soyinka's The Trials of Brother Jero is a "bitter criticism of religious and political roguery that have become rampant worldwide particularly in post-colonial Africa and his own Nigerian society" (p. 282). In its five scenes, a fraudulent amateur, Jeroboam, masquerading as a true prophet of God uses slander and deceit to dupe and amass wealth from a small congregation that foolishly overdepends on him for divine providence. With prophesies and sermons of prosperity, he utterly leads the lowest (Chume, the office messenger) to the highest in the society-the Member of Parliament, to a vain hope of a better future. His true flaws are finally revealed when Chume discovers through Amope that Brother Jero is a debtor and a slanderer. To Chume's dismay, the self proclaimed prophet is merely an "Adulterer! Woman- thief" (Soyinka, 1996, p. 28). The main cast include: brother Jero, Chume, Amope, Drummer boy, the trader, the Old prophet, penitent, Member of Parliament, neighbors, villagers and worshippers.

\section{The Pursuit of Happiness Brother Jero}

Brother Jero is one of the most conflicted and unhappy characters in the play. On one hand, he is an unbelievably corrupt and disgustingly shameless, yet on the other, incredibly cowardly. Because of his twisted conception of happiness and an overwhelming ambition, he yields to his emotional rather than rational part of his brain. To him, happiness is being wealthy, honorable and sexually satisfied. He therefore worships himself, steals from others and lustfully admires women he knows he can't have- all in a worthless attempt to be happy.

Right at the beginning of the play, Soyinka introduces him to the audience in the most ridiculous soliloquy in which he describes himself as a selfmade- better- than- others prophet. He calls himself "the Immaculate Jero... Articulate Hero..." (Soyinka, 1996, p. 23), names which are less befitting to the villain we know he is. One is surely bound to think that with this pride, his ultimate goal is honor and that with such honorable names, he is fulfilled but the opposite is true. His entire life is a miserably futile journey in search of honor, an end that Aristotle does not regard as happiness since honor is not an end in itself but something sought so that one can be happy.

He has grown taller than life such that other characters are mere shadows under his "mighty" spell. To him, "there are eggs and there are eggs!" (Soyinka, 1996, p. 7), meaning that he is the real deal and others are just armatures. He refers to Chume, his most loyal disciple as "... too crude" (Soyinka, 1996, p. 16); his predecessor, the old prophet, as a foolish dodderer (Soyinka, 1996, p. 8), the member of parliament as a "poor fish" (Soyinka, 1996, p. 7), and Amope as the evil daughter of discord (Soyinka, 
1996, p. 22). For such a vice, Aristotle would regard Jero a fool and prescribe high mindedness as the golden mean.

Without a doubt, it is very unlikely

for Jero to hit this mark of highmindedness because his pride is colossal, making it even harder for him to be happy. One might decide with conviction that Jero's pride is a major hindrance to his happiness. He feels he is too good for others. When describing his appearance, he emphasizes how handsome he is. "You must admit that I am rather good looking...no, don't be misled, I am not at all vain." (Soyinka, 1996, p. 8). While a low self-esteem is deficient, a self conceited pride is an excess and Jero conveniently misses the mark which is self-control. Like Jero, many people struggle with self pridethe "I". In his chase for honor, he minimizes others and considers them as lesser extensions of human beings. This only serves to show how truly unhappy he is.

Jero is also a manipulative shameless thief who has turned religion into business in an attempt to attain happiness. His main skill is in duping others and amassing wealth. He proclaims: “...I was born a natural prophet. And I grew to love the trade", the word "trade" Mireku (2013) suggests, becomes indistinct given it could connote the prophet hood, ordinarily, or a money-making business where the accent is on moneyconsciousness. The church is his market and the worshippers- the customers. He confesses, "I am glad I got here before any customers- I mean worshipperswell, customers if you like. I always get that feeling every morning that I am a shop-keeper waiting for customers" (Soyinka, 1996, p. 14-15). He fully understands their flaws and gullibility yet he exploits them to exhaustion in a bid to be wealthy- a status he believes will make him happy. This pleasurable venture only gives a short lived satisfaction and makes him a very unhappy man. Aristotle submits, "for as it is not one swallow or one fine day that makes a spring, so it is not one day or a short time that makes a man blessed and happy" (Nicomachean Ethics, 1985:1098a18).

If Jero's call is to be a prophet, he should do it with excellence in order to be happy. However, his actions are everything but those of a true prophet. Through his fake prophecies, he has managed to capture a few ignorant people whom he feeds with one lie after another. He takes pleasure in keeping them dissatisfied (unhappy) because satisfaction (happiness) as he claims will keep them away. Indeed, Aristotle contends that, "that which is always desirable in itself and never for the sake of something else" (Nicomachean Ethics, 1985:1097a30-34), is happiness. He knows that if Chume beats Amope he will be happy and will not need him. He prides in his follower's vulnerability and uses their ambitions for his own gain. He audaciously confesses,

\footnotetext{
This one here who always comes earliest, I have prophesied that he will be made a Chief in his hometown. That is a very safe prophecy. As safe as our most popular prophecy, that a man will live to be eighty. If it doesn't come true ... that man doesn't find out until he is on the other side. So everybody is quite happy. One of my most faithful adherents, unfortunately, he can only be present at weekends - firmly believes that he is going to be the first Prime Minister of the new Mid-North-East State when it is created. That was a risky prophecy of mine, but I badly needed more worshippers at that time. (He looks at his watch.) The next one to arrive is my most faithful penitent. She wants children, so she is quite a sad case. Or you would think so... (Soyinka, 1996, p. 18).
} 


\section{Christine Osae}

The Quest for Happiness in Wole Soyinka's the Trials of Brother Jero

This passage underscores a few points as far as happiness is concerned. Firstly, Jero himself admits that happiness is achievable after death: "if it doesn't come true ... that man doesn't find out until he is on the other side. So everybody is quite happy (Soyinka, 1996, p. 18); one then wonders why he single-mindedly chases after what he can't have. Secondly, he admits that wealth will make him happy so as long as men keep attending his church, money won't be an issue. How absurdisn't he the same Jero jumping off the window because he is running from a creditor whose debt he has failed to pay? Thirdly, there is a varied understanding of the concept of happiness. While the naïve minister thinks political status is a true end to happiness, the barren woman believes that having a child will bring happiness. At the end of the day, the question is not what brings happiness but whether or not you are happy. Finally, this passage also portrays Jero as a villain who does not deserve to take advantage of good innocent people in the society. Soyinka brusquely satirizes the likes of Jero in the society who constantly prey on innocent victims. Such are the traits of unhappy people whose lives are utterly empty.

In addition to the above, Jero shamelessly steals from his poor followers and is not even decent enough to pay his debts. He is portrayed as a man who will stop at nothing to get what he wants. After grabbing land from the old prophet and sending him away unceremoniously, he ambitiously sets his eyes on the beach. He says, "if only I had this beach to myself" (Soyinka, 1996, p. 14). He is utterly devoid of any sympathy for Chume whose predicament at the hands of a tyrannical nagging wife he fully understands. He sadistically prides in keeping his congregators "dissatisfied"
(Soyinka, 1996, p. 15). Ambition is not bad, but the overwhelming need to have everything at all cost is an excess which Aristotle argues must be moderated to a balance- a golden mean. Only then can one attain happiness.

Similarly, Jero's lack of remorse for his own wrongs makes him a sadist. He remains unrepentant even after Chume confronts him with the truth. Instead, he intends to inflict more grief. He makes his malevolent plans very lucid when he says,

I have already sent for the police. It is a pity about Chume .... With the influence of that nincompoop, I should succeed in certifying him with ease. A year in the lunatic asylum will do him good anyway... And so the day is saved. The police will call on me as soon as they catch Chume. And it looks as if it is not quite time for the fulfillment of that spiteful man's prophecy (Soyinka, 1996, p. 30).

This is not in line with Aristotle's doctrine of happiness. According to Aristotle, "happiness [is] an activity of the soul in accordance with virtue" (Nicomachean Ethics, 1985:1098a13). There is nothing even remotely virtuous about hurting others, much less rejoicing in the same. When at the end of the play we still meet him planning how to dupe the Member of Parliament, we are sure Soyinka intends to highlight man's nature to err. Even though the measure of happiness can be defined at the end of one's life, Jero is not a happy man and all his attempts to attain happiness seem futile as he is going about it the wrong way.

It is ironical that a man too confident as to robe his congregators in daylight should be so frightened by a woman. Jero, the self proclaimed hero stoops so low as to escape his own house through the window at the scare of Amope, a tyrannical woman, who is determined to settle the scores. 
According to Aristotle, cowardice is a vice but so is foolhardiness. Jero must strive to hit the mark which is couragecourage to confess that he is not a true prophet; courage to face Amope and pay his debts; courage to live in his own house without begging; courage to find a decent job. It is only through this that he can lead a truly happy life. It can therefore be said that Jero is his own obstacle to happiness.

According to Aristotle, if one attains the golden mean, they are regarded as good people in the society. However, Jero is considered as a "bearded rogue", "a thief of a prophet" (Soyinka, 1996, p. 13) and an "adulterer", "woman-thief" by Chume (Soyinka, 1996, p. 30). It is quite clear here that Jero is lost in the two polarities of excesses and deficiency as opposed to the balance point. He is a man of err just like any other. Aristotle says "he who observes the mean, being a man who is "always himself", is truthful in word and deed, confessing the simple facts about himself, and neither exaggerating nor diminishing them"

(http://www.gradesaver.com/aristotle s-ethics/study-guide/summary). In Jero's pursuit for happiness, he greatly messes up and ends up an unhappy man hunted down by all. Because of his infamous life style, he ends up without any true friend but a trail of enemies seeking his blood in vengeance. The Jeros in this contemporary time should surely learn that evil never breeds any good.

While his tact and manipulative intelligence are admirable, how dirty he is willing to play just to be honorable and wealthy is disgusting. Soyinka's point here is that intelligence is a virtue but when cunningly used for mischief, becomes a vice. All these vices make
Jero exceedingly unhappy;

consequently, it can be ascertained that Jero will never find happiness unless he behaves well.

\section{Chume}

Chume is Jero's most devoted adherent. Yet even his religious commitment does not suffice to bring him happiness. To him, happiness can be attained by pleasing God, getting a good job and beating his wife. He is the one we most empathize with because he is gullible and nauseatingly naïve. For example, it is baffling how Chume completely trusts Jero with issues concerning his marriage and does not sense any foul play when suddenly Jero decides that Amope, Chume's wife, deserves a beating. He is defenseless to both his authoritarian strong willed nagging wife and the shrewd deceitful Jero. Jero assures him that, "...this woman whom you so desire to beat is your cross. Bear it well. She is your heaven sent trial" (Soyinka, 1996, p. 18). The cross connotes a burdensomething that enslaves. Jero encourages Chume to stay in slavery of unhappiness because he (Jero) does not want to lose a follower. For this reason, he is constantly unhappy as he does not exercise his own will. His vulnerability is a vice because it is not a sign of humility but rather delicate stupidity. Chume blindly follows Jero. He clearly has no understanding of religion or God. Mireku (2013) argues that, "despite the triviality and meanness of what is prophesied as prosperity for him, we find Chume trusting in the abilities of Jero" (p. 276). She adds that considering how engrossed in prayer where he repeats, vehemently, unrealistic demands for better life, which are unlikely to get to him, we cannot help but sympathize. Chume is 


\section{Christine Osae}

The Quest for Happiness in Wole Soyinka's the Trials of Brother Jero

evidently the saddest character in the play.

Although too trusting and annoyingly immature, it can be argued that he is the only character who demonstrates self control and gentleness in scores of encounters. A wife like Amope can make even the politest of men go gaga! After agonizingly (his legs can barely reach the peddle, so it is a struggle) transporting his wife to the prophets house, he is rewarded with nothing but obscenities. He must put up with constant nagging and disapproval from his wife. She exclaims: "a Chief Messenger in the Local Government Office- do you call that work? Your old school friends are now ministers riding in long cars... he's no worse than other men but, he won't make the effort to become something in life" (Soyinka, 1996, p. 11). However, instead of beating the arrogance out of her, Chume goes for prayers. This is self-control, a virtue that should reward him with happiness amidst the maze of hostility he endures from his wife.

He constantly rewards the nags with compassion. When Amope complains of an aching foot, he offers to bandage it even when he knows she is exaggerating (Soyinka, 1996, p. 10). He is late for work but patiently listens through his wife's arrogance without bursting into fury a reaction we can barely understand because his fury is heightened when he explains his problems to Jero later on, "this woman will kill me" (Soyinka, 1996, p. 17). Nevertheless, going by Aristotle's submission as quoted by Koven (2015), "equilibrium is the right feelings, at the right time about the right things, toward the right people, for the right end, and in the right way"

(Nicomachean Ethics, 1985:1106b, p. 15-29) In this case, Chume can be considered virtuous despite his naivety.
He hits the mark yet even then is still unhappy.

Even when he finally discovers that Jero is a scum, he projects his anger towards him and not his wife. His initial intent is to beat the wife but when he discovers the foul play; his fury is immediately turned to the root cause of the problem- the prophet. Fighting is a vice but Aristotle clearly states that if this vice is directed towards the right person at the right time for the right reason, it is no longer a vice but a virtue (Nicomachean Ethics, 1985:1106b, p. 15-29). One would argue here that fighting is a vice but considering the mischief Jero has been up to, he deserves to be put in his place. So once again, Chume hits the golden mean of virtue. Aristotle agrees that:

$$
\begin{aligned}
& \text { He then who is angry on the right } \\
& \text { occasions and with the right persons, and } \\
& \text { also in the right manner, and at the right } \\
& \text { season, and for the right length of time, is } \\
& \text { praised; we will call him gentle, } \\
& \text { therefore, since gentleness is used as a } \\
& \text { term of praise. For the man who is called } \\
& \text { gentle wishes not to lose his balance, and } \\
& \text { not to be carried away by his emotions or } \\
& \text { passions, but to be angry only in such } \\
& \text { manner, and on such occasions, and for } \\
& \text { such period as reason shall prescribe. But } \\
& \text { he seems to err rather on the side of } \\
& \text { deficiency; he is loath to take vengeance } \\
& \text { and very ready to forgive (Peters, } 1893 \text { : } \\
& \text { IV. } 5,4 \text { ). }
\end{aligned}
$$
But the deficiency, call it wrathlessness or what you will-is censured. Those who are not angered by what ought to anger them seem to be foolish, and so do those who are not angry as and when and with whom they ought to be; for such a man seems to feel nothing and to be pained by nothing, and, as he is never angered, to lack spirit to defend himself. But to suffer one's self to be insulted, or to look quietly on while one's friends are being insulted, shows a slavish nature (Peters, 1893: IV. 5, 6).

The portrait of Chume in this play is an indication that happiness is 
extremely elusive. Despite Chume's virtuous acts, he is still unhappy. Secondly, Chume's portrait also indicates that quest for happiness if done virtuously but with no maturity of reason can be futile.

\section{Amope}

Amope, unlike Chume, is very hard lined, distressing and narcissistic. Having deeply observed the society, she has come to a conclusion that this is how to deal with people if she is to get what she wants. She believes that justice brings happiness. Her confrontation with the prophet is an attempt to get back her money- justice. When she bargains the price of fish, it is just an indictment against extortionjustice. Even her encounter with the drummer is just a proclamation that people should work hard to earn what is rightfully theirs instead of merely begging. Soyinka's plot to reveal the false prophet through further presents her as the tool for justice. The question however is, is this justice an end to itself or will it bring her happiness?

In her pursuit of justice and ultimately happiness, she abuses every one with whom she comes into contact. Mireku (2013) describes her as, "a truly wicked woman because in spite of the husband's shortcomings, she tends to be too disrespectful to him (p. 279). When she is introduced to the audience, the portrait is of a woman complaining of everything and nothing worthwhile in particular. Her complains soon turn into a trail of sarcastically derogative comments that inevitably send Chume into rage. One would think that Amope is absolutely devoid of even an iota of civility. What is certain however is that she is unhappy. Through her, Soyinka seems to suggest that justice is good but the means of achieving it, if immoral, taints the course.

The trail of obscenities she hails at the self proclaimed man of God is beyond belief. When Jero warns her of pride, she responds with an insult: "Listen, you bearded debtor" (Soyinka, 1996, p. 12). The opener, "listen" seems to suggest she is in control but what follows next indicates that she is not exactly in control of her on temperament or haughtiness. This overconfidence is what Aristotle calls a vice and he suggests that until man moderates it to valor- the golden mean, virtue hasn't been reached.

Consequently, without virtue, man cannot lead a truly happy life.

The prophet is however not his only victim. She becomes even more ridiculous in her encounter with the trader who, by the way, is just as discourteous. One may agree with Brother Jero that women are daughters of discord.

A keen consideration of her encounter with the trader (Soyinka, 1996, p. 12-13), reveals that Amope is the offender. Aggressively, she turns the negotiations to insults. She is the first to maliciously complain that the fish smells. A critical reader might deduce that this is just an excuse so she can spend less- a vice which according to the doctrine of the golden mean is stinginess. Assuming this was true and that Amope in this case should strive for magnificence, her stinginess given her economic status would not be considered a vice. Had she been a rich lady yet underpaying for goods, one should straight away regard her behavior as bad. Peter (1893) quoting Aristotle, states that:

A poor man cannot be magnificent: he has not the means to spend large sums suitably: if he tries, he is a fool; for he 


\section{Christine Osae}

The Quest for Happiness in Wole Soyinka's the Trials of Brother Jero

spends disproportionately and in a wrong way; but an act must be done in the right way to be virtuous. But such expenditure is becoming in those who have got the requisite means, either by their own efforts or through their ancestors or their connections, and who have birth and reputation, for all these things give a man certain greatness and importance (IV. 2, 13).

However, others may regard this act as a pure push for justice in pricing goods. Clearly, her pursuit for happiness is a pain to others with whom she comes into contact as she is arrogant and offensive. Even a Drummer who has committed no offence tastes of Amope's cup of wrath. Without any prior exchange, Amope turns her anger to the boy: "take yourself off you dirty beggar. Do you think my money is for the likes of you? I don't know what the world is coming to. A thief of a prophet, swindler of a fish seller and now that thing with lice on his head comes begging for money" (Soyinka, 1996, p. 13).

Amope's foolhardiness is also worth comment. She is portrayed as a fearless character who tackles the bull by the head. When we first meet her, she has her bags parched and is camping at Jero's door until she is paid her debt. As soon as Jero appears, she fearlessly confronts him making her intentions very clear. No amount of dissuasion from her husband will make her recoil. In the public fight she finally has with Chume, she dangerously dares him to beat her. Knowing how furious Chume is, the audience is scared that she will be killed but she doesn't care. She dares him to: "Kill me! Kill me! I won't get on to that thing unless you kill me first (Soyinka, 1996, p. 25). Clearly, Chume is exercising a delicate yet unlikely kind of self control. Very few people, if any would put up with this kind of temptation.
By juxtaposing the two characters, Soyinka clearly portrays Amope's pomposity and foolhardiness to make it clear that an end may be justified and good but only if the means to the end are equally good. Had Amope exercised self restraint, she would be a happy person. Nevertheless, this is still debatable since Chume is the most self restrained yet very unhappy. Mireku (2013) admits that "Even though we do not side with Amope's insulting habit, we admire her industry and desire to succeed. Above all, we admire her refusal to be cowed before a man: an opportunistic Christian leader at that" (274).

\section{CONCLUSION}

An in-depth study of Soyinka's the trials of brother Jero proves that true happiness is elusive and unachievable. All the major characters analyzed display futile attempts to pursue happiness and how this pursuit makes them villainous since it tends to be selfish. Each of these characters has varied opinions concerning what brings happiness.

To Jero, wealth, honor and sexual satisfaction are ends to happiness. Chume however feels that beating Amope and getting a good job will make him happy. Amope on the other hand seeks justice as a means to happiness. The barren woman seeks a child to make her happy but the Member of Parliament thinks political fame is the source of happiness. At the end of the day, they are all unhappy as they fail to attain these desires.

In this play, Soyinka also makes an important point that the end should not justify the means but vice versa. All these characters display wickedness in a bid to be happy. Just like Aristotle (1985) suggests, "happiness turns out to be an activity of the soul in accordance with virtue (Nicomachean 
Ethics, 1985: 1098a13). Aristotle would be strongly critical of wickedness in the pursuit of happiness.

\section{REFERENCES}

Aristotle. (1985). Nichomachean Ethics. Indianapolis: Hackett Publishers.

Aristotle. (1893). The Nichomachean Ethics of Aristotle (5th ed.). London: Kegan Paul, Trench, Truebner \& Co.

Bremner, R. H (2011). Theories of happiness: On the origins of happiness and our contemporary conception. Retrieved from: http://hss.ulb.unibonn.de/2011/2597/2597.pdf retrieved on 20/08/2016.

Golden Mean. Retrieved from http://www.anus.com/zine/articles/d raugdur/golden_mean/.
Golden Mean (philosophy). Retrieved from: http://www.newworldencyclopedia.or g/entry/Golden_mean_(philosophy)

Koven, S. (2015) Responsible governance: A case study approach. Retrieved from: https://books.google.com/books?

Kenny, C. (2002). The philosophy of happiness. Retrieved from http://charleskenny.blogs.com/weblo g/files/kenny_chapter_1.pdf.

Tosin, T. (2015). The pursuit of happiness: what is happiness, and how can we make ourselves happier? Retrieved from

http://www.unc.edu/ gsmunc/phil22 /Nicosum.pdf.

Wole, S. (1996). The Trials of Brother Jero. New York: Dramatists Play Service, INC 